\title{
THE ASSOCIATION OF UNIVERSITY TEACHERS
}

$T$ HE Association of University Teachers were the guests of the Southampton Association of University Teachers and the University of Southampton during December 17-20, and their meetings were presided over by Prof. W. W. Chambers of the University of Glasgow.

The deliberations were dominated by the effects of the ('overnment's financial policy towards universities. The offocts which were roported to the Council included losses of staff, failuro to provide places for some 2,500 wellqualified candidates and postponement or changes in plans for expansion affecting overy institution in the United Kingdom and Northern Ireland. Although most attention was given to problems of expansion, the longdolayed issue of salaries gave rise to heated debate when representatives learned that the claim for increases of about 30 per cent, substantially agreed with the vicechancellors, had not been discussed with the University Grants Committee, as provided for in the procedure laid down by the Treasury. The University Grants Committeo had not arranged the necessary meoting. This news, together with Press reports and rumours that the matter was to be referred to the not yet constituted National Incomes Commission, led to demands that the subject be taken up with the Chancellor of the Exchequer through Parliament. The Council in a resolution objoctod to the diserimination inherent in the National Incomes Commission but left the Association free to present data to the Cominission if university salaries were reforred to them by the Government.

The discussion of university expansion was centred on what was described as the "18 + Crisis", and the Council passed a policy resolution submitted by Liverpool:

"That the policy of the A.U.T. on expansion should be based on the following principles:

"(1) The A.U.'T. recognizes and welcomes the necessity for a substantial expansion of the universities for reasons both of national neod and social justice. It insists, how- ever, that neither purpose will be served if oxpansion loads to deterioration in the quality of the education offered.

"(2) The special quality of university education derives from the active participation of university teachers in fundamental research and scholarship. Therefore, the A.U.T. regards the provision of adequate time and facilities for those activities to be essential to the successful fulfilment of the universities' role.

"(3) Tho A.U.T. considers that the maintenance of the quality of university education must have precedence over expansion if lack of money or other resources forces a choice. No lowering of essential standards can be contemplated.

"Tho first duty of the A.U.T. in the present situation is to intensify the campaign for an immediate and substantial increase in the resources available to the univer. sitios.

"Further, it is the duty of the A.U.T. to warn the public that grave injury to the national economy will result if university research is sacrificed in an attempt to expand undergraduate teaching without the necessary resources."

The Council then went on to discuss proposals for making the problems of university expansion widely known to the general public.

The growth of the Association to a membership of some 10,000, almost all non-medical university teachers, in universities other than Oxford and Cambridge had created problems of organization which were the subject of furthor discussion, and proposals were made for changing the form of one of the half-yearly meetings.

Other matters which were discussed included proposals to improve the status of university technicians, the problems of student selection and the improvement of general degrees and possible ways of raising the popular esteom of the general degree.
D. Chapman

\section{ZOOLOGICAL EXPEDITIONS}

$\mathrm{T}$ He twenty-eighth annual moeting of the Association of British Zoologists was held at the Offices of tho Zoological Society of London on January 5. The president for 1963 , Dr. F. Fraser Darling, was unable to attend, and the chair was taken by Prof. C. F. A. Pantin. After the business meeting several papers were read on "The Sciontific Aims, Planning and Rosults of Zoological Expeditions".

Mr. N. A. Holme (Plymouth) outlined his present work investigating the bottom of the English Channol. Since the pioneer drodging activities of the Porcupine and Challenger expeditions the faunistic exploration of the benthos is now fairly complete, except for the deep sea. In the English Channel the presont survoys are concerned with assessing biomass and productivity, dispersal and aggregation, and the factors which limit the distribution of bottom-living animals. Thore is no ideal sampling apparatus, either qualitativo or quantitative: trawl, drodge, Potersen bottom-sampler, anchor-dredge and automatic camera all have their disadvantages. On a rapid survey only one type of gear can be used at each station, and Mr. Holme stressed the importance of careful planning to make the most of the ship's time. After dealing with tho practical aspoets of sorting, presorving and working-up samples of benthos, Mr. Holme made a plon for the early publication of results.
Dr. Anna Bidder (Cambridgo) gave a lively account of her trip to the South Seas to study living specimens of the poarly nautilus in 1960-61. Local pooplo in Now Caledonia, the Loyalty Islands and New Britain brought her Nautilus caught in traps baited with putrescent fish and meat. In this way she was ablo to study, in the public aquarium at Nouméa or, elsewhere, in aquaria improvised from slop-basins on the foreshoro, specimens of three spocies of this nocturnal, bottom-living molluse. The chambered sholl of the pearly nautilus has been sung by poets and worked over by overy zoology student, and yet, we have known scarcely more than Aristotle could tell about tho habits of the animal within. Now Dr. Bidder has not only boon able to confirm the Aristotolian account. but answer much which was speculativo concorning onc of the most bizarre forms of cephalopod radiation.

Prof. C. F. A. Pantin (Cambridge) described how, during a war-timo holiday, his chance find in an English oakwoorl of the terrestrial nemertine worm Geonemertes lod him in subsequent years to pursue studies on the taxonomy and world distribution of this genus, and on its anatomy, physiology and ecology, whenover opportunity could afford during visits to Europe, Africa, New Zealand and various oceanic islands. Prof. Pantin made the point. which was further emphasized in discussion by Prof. G. C. Varley (Oxford), that whereas the objectives of an expedi. 
tion should be carefully defined, the members of the expedition should have a sufficiently wide background to take advantage of the unexpected opportunity or the sideline which sometimes may lead to the most rewarding results. Prof. Pantin also suggested that in all universities the young graduate proposing to undertake research should first be given the opportunity of an 'expedition year', a year in the field which would yield experience of real value irrespective of the kind of research eventually pursued.

The University of Cambridge Expedition to British Honduras in 1959-60 was a considerable enterprise where ten undergraduates worked in the field for eleven months on a comprehensive programme including archæology, botany, zoology and physiography. Mr. P. K. Bregazzi (Cheltenham College) described the zoological work which was mostly concerned with the faunal ecology of the corals and the land ecology of the cays which lie scattered within a broad channel between the shore and a long fringing reef. Using mostly skin-diving methods the party lived much of the time in a small sailing-boat with which they managed to explore 150 miles of the channel. Interesting results were obtained on the diurnal activity of coral polyps and on the origin of 'beach-rock' formations on the islands, but Mr. Bregazzi concluded that the work was chiefly significant as the first step in a long-term programme and he noted that the area had since been visited by at least five expeditions from Britain and the United States.

An expedition with a careful programme in applied science was described by Mr. P. D. Fry (Royal Veterinary College). In 1962 eight undergraduates visited East Africa to study so far as they could the diseases which affect wild mammals and birds and domestic cattle, and to collect material which might show how these diseases affect man. Special attention was directed to game animals likely to be included in cropping programmes. Travelling in 'Land-Rovers' the party in ten weeks got through a great deal of work, mostly in Uganda, where they were able to examine more than 200 animals ranging from the spiny mouse to the elephant. Systematic autopsies yielded pathological material and parasites, and there were collections of blood-smears and blood sera for studies on protozoal disease and on immunology. Some of the collections were from game anæsthetized with the 'capchur' gun. A notable feature of this expedition, to which Prof. Varley directed attention, was its active co-operation in the field with medical and veterinary research organizations of Uganda and Kenya, and the approval and patronage it won from the World Health Organization.

Dr. Robert Clarke (National Institute of Ocean ography) summarized the discussion and concluded with some general observations. He recalled that the exploratory expedition in zoology had, in the past thirty years, mostly given way to specialized objectives in evolution, physiology and especially ecology. The emphasis was now on pro- ductivity, both by land and sea, and he welcomed the kind of expedition described by Mr. Fry which had avowed economic ends in a world hungry for proteins. The planning of expeditions should take realistic account of possible hitches in the field, so that, as mentioned by Mr. Holme, any lengthy or costly expedition should have alternative programmes which (combined, as it may be, with the readiness to improvise) can in the event turn some impending failure into success. Only the enthusiast like Dr. Bidder, going out alone, could afford a single objective and be almost sure to achieve it. Working up results at home, an expedition always brings back more material than it can deal with. Great colloctions build up over the years, and there was an urgency in Prof. Pantin's plea for more taxonomists in professional zoology. Even an expedition with the most radical aims in applied science must know what the animals are - be they a food resource or a disease vector.

Reviewing the general trend of expedition activity, Dr. Clarke noted that the major expeditions were national undertakings until about ten years ago. Their era was one of great achievement, and by example he mentioned the work of the vessels of the Discovery Expedition and the National Institute of Oceanography which between 1926 and 1951 had made the remote Southern Ocean the best known seientifically of the world oceans; but he welcomed the present trend towards international co-operation in the expeditionary field. Such activity has mainly been at sea, and in its modest way a beginning was made by the Enern's voyage to the Antarctic in 1953 when Norwegian, Dutch and British scientists collaborated in a whale-marking expedition. Development of the largescale venture has been assisted by the growth of international organizations like the International Council of Scientific Unions and the specialized agencies of the United Nations which have provided the administrative machinery. The International Indian Ocean Expedition, in which ships of thirteen nations are engaged, will be especially active in 1963 , and in this year also five nations will co-operate in surveying the equatorial region of the Atlantic. International relations could not but benefit from such work, and it was heartening to mention in conclusion another aspect of the co-operative expedition which he illustrated from a recent mission with the Food and Agriculture Organization to the west coast of South America. No traveller could have failed to notice that past expeditionary work in the countries of Asia, Africa and Latin America has mostly been the enterprise of Europeans and North Americans. But it was desirable that the nationals of these countries should explore their own deserts and rain forests and seas. Enthusiasm was not lacking, and now, with the development of technical assistance programmes of the United Nations and of bilateral organizations, the necessary aid and training had become available and was already in the field.

Robert Clarkf

\title{
THE GALE OF FEBRUARY 16, 1962, IN THE WEST RIDING OF YORKSHIRE
}

\author{
By C. J. M. AANENSEN and J. S. SAWYER \\ Meteorological Office, Bracknell, Berks
}

\begin{abstract}
$\mathrm{V}^{\mathrm{n}}$ ERY many people living in and around Sheffield will remember for a long time the disastrous westerly gale of February 16, 1962. The gale commenced at about 0430 G.M.T. in the West Riding and continued for the next $8 \mathrm{~h}$. In Sheffield alone 101,500 dwellings out of a total of 161,000 dwellings were damaged in one way or another, and 98 dwellings (including 69 prefabricated houses) were damaged beyond repair. Elsewhere through-
\end{abstract}

out a broad belt running northwards parallel to the Pennines from North Derbyshire to Northumberland very considerable damage occurred to both buildings and trees.

As soon as the scale of damage became known, Meteorological Office staff in the area made a survey of the type and distribution of damage and later some theoretical and climatological aspects of the storm were considered 